\title{
СУТТЕВІ ПРОБЛЕМИ ТА РИЗИКИ СУЧАСНОЇ ВИЩОЇ ОСВІТИ: НОРВЕЗЬКИЙ ДОСВІД ЇХ ЗАПОБІГАННЯ ТА РОЗВ'ЯЗАННЯ
}

\section{Д. В. Желанов}

Харківський національний педагогічний університет імені Г. С. Сковороди

вул. Валентинівська, 2, Харків, Україна E-mail: zhdv91@gmail.com

У статті висвітлюються більш суттєві проблеми та ризики вищої освіти у контексті сучасних процесів глобалізації та євроінтеграції. Акцентується увага на проблемах професійного вибору сучасної молоді; зв’язку вищої освіти з ринком парці; нестачі висококваліфікованих кадрів; працевлаштування випускників закладів вищої освіти; відсутності зв'язків між освітянами та працедавцями; трансформації сучасних систем освіти в утилітарно-прагматичному напрямку; «дегуманізації» сучасної вищої освіти. Розкрито досвід вищої освіти Норвегії щодо запобігання й розв'язання ії проблем та ризиків. 3'ясовано, що особливостями вищої освіти Норвегії $є$ такі, як-от: егалітарність, централізованість, соціальна зорієнтованість, рівність освітніх можливостей, інтернаціоналізація; поширеність спеціалізованих інститутів, реалізація «трикутника знань».

Ключові слова: проблеми та ризики вищої освіти, ринок праці, еглітарність освіти, інтернаціоналізація освіти, дегуманізація освіти, спеціалізовані інститути, «трикутник знань».

\section{СУЩЕСТВЕННЫЕ ПРОБЛЕМЫ И РИСКИ СОВРЕМЕННОГО ВЫСШЕГО ОБРАЗОВАНИЯ: НОРВЕЖСКИЙ ОПЫТ ИХ ПРЕДУПРЕЖДЕНИЯ И РЕШЕНИЯ}

\section{Д. В. Желанов}

Харьковский национальный педагогический университет имени Г. С. Сковороды

ул. Валентинивська, 2, Харьков, Украина. E-mail: zhdv91 @ gmail.com

В статье освещаются наиболее существенные проблемы и риски высшего образования в контексте современных процессов глобализации и евроинтеграции. Акцентируется внимание на проблемах профессионального выбора современной молодежи; связи высшего образования с рынком труда; недостатка высококвалифицированных кадров; трудоустройства выпускников заведений высшего образования; отсутствия связей между педагогами и работодателями; трансформации современных систем образования в утилитарно-прагматическом направлении; «дегуманизации» современного высшего образования. Раскрыто опыт высшего образования Норвегии по предотвращению и решению ее проблем и рисков. Выяснено, что особенностями высшего образования Норвегии есть такие, как: эгалитарность, централизованность, социальная ориентированность, равенство образовательных возможностей, интернационализация; распространенность специализированных институтов, реализация «треугольника знаний».

Ключевые слова: проблемы и риски высшего образования, рынок труда, еглитарнисть образования, интернационализация образования, дегуманизация образования, специализированные институты, «треугольник знаний».

АКТУАЛЬНІСТЬ РОБОТИ. Глобалізаційні та євроінтеграційні процеси, що стали суттєвою рисою всіх сфер сучасного суспільства, актуалізують важливість проблеми підвищення конкурентоспроможності національної економіки, оптимізації використання трудових ресурсів. При цьому важливою умовою інтенсивного розвитку ринку праці є реалізація професійного потенціалу громадян країни, що значною мірою залежить від обгрунтованості їхнього професійного вибору. Існує наукова позиція щодо трактування професійної компетентності особистості у контексті ії професійного вибору, а саме як комплексної науково обгрунтованої системи практичних методів і засобів впливу на особистість з метою забезпечення самостійного й усвідомленого вибору професії, іiі освоєння та здійснення професійної діяльності на основі врахування індивідуально психологічних властивостей людини і потреб ринку праці в кадрах [1]. При цьому головну роль в цьому сенсі відіграє вища освіта. Не можна не погодитися 3 Г. Хоружим, який стверджує, ще заклади вищої освіти $є$ основою наукового, дослідницького і технологічного розвитку європейських країн. Більш очевидним стає тісний взаємозв'язок освіти з економікою, яка визначає матеріальну базу сфери освіти, зумовлює ії зміст, визначає перелік необхідних для суспільства спеціальностей і професій, структуру навчальних дисциплін. 3 іншого боку, вища освіта готує кадри, необхідні для вирішення економічних завдань, розвитку сучасних технологій, забезпечує накопичення суми знань, необхідних для прогресивного розвитку [2].

Тобто окреслені тенденції вищої освіти актуалізують необхідність вивчення досвіду України, а також європейського досвіду розв'язання ії більш суттєвих проблем та ризиків, зокрема досвіду Норвегії.

Варто відзначити, що останніми роками в Україні посилилася увага до дослідження різних аспектів модернізації вищої освіти та підготовки фахівців за кордоном (Н. Абашкіна, Ю. Бекетова, М. Бершадська, Л. Віннікова, Н. Гайдук, М. Дмитриченко, В. Зубко, О. Карпенко, I. Козубовська, С. Когут, К. Корсак, Т. Кошманова, Н. Лавриченко, Г. Лещук, О. Матвієнко, Н. Микитенко, Н. Ничкало, О. Павлішак, В. Поліщук, О. Пришляк, Л. Пуховська, А. Сбруєва, Г. Слозанська, С. Сисоєва, В. Семілетко), що $є$ позитивним явищем. Водночас простежується деяка звуженість тематики досліджень щодо країн Скандинавії, зокрема Данії, Норвегії і Швеції. Проте Данія, Норвегія, Швеція належать до країн, які за показниками розвитку освіти мають найвищі світові рейтинги та їх вища освіта, будучи складо- 
вою частиною європейського освітнього простору, $є$ носієм його основних характеристик, що досліджують вітчизняні та зарубіжні науковці: А. Кулікова, О. Огієнко, Л. Филипповець, Е. Коккерсволд, Р. Лаппен, Т. Логвіненко, Р. Лунгстад, Я. Петерсон, Р. Расмуссен, Н.-Е. Свенссон, В. Сьюпаул, В. Тевліна, Т. Хьюсен, Т. Йєнсен, П. Шернквіст, С. Юліусдотір, Д. Якобсон та ін.

Мета статті полягає у висвітленні сучасних ризиків та проблем вищої освіти та аналізі особливостей норвезького досвіду їх розв'язання.

МАТЕРІАЛ I РЕЗУЛЬТАТИ ДОСЛІДЖЕНЬ. Останнім часом випускники навчальних закладів являються певним «товаром», який користується підвищеним попитом. Сьогодні все помітнішою на ринку освіти стає нова особа - роботодавець. При цьому важливе місце відводиться тісній співпраці науки, освіти та інноваційної діяльності. Така інтеграція дає змогу роботодавцям дієво брати участь у формуванні та оснащенні освітніх програм, закладати в умови спеціалізації свої технологічні «платформи», активно знайомитися з майбутніми випускниками, залучаючи їх для проходження практики та участі в проектах зі своєї проблематики. Цей взаємозалежний тандем між закладом освіти і роботодавцем зумовлює певний формат соціального партнерства, який дає можливість залучати до участі в роботі державних екзаменаційних комісій висококваліфікованих фахівців з виробництва, можливість викладачам університетів проходити стажування на підприємствах 3 метою ознайомлення із сучасними технологіями, можливість студентам проходити різні види практик на сучасному виробництві [3].

До того ж у останній час суттєво загострилась проблема нестачі висококваліфікованих кадрів, 3 одного боку, та труднощів у працевлаштуванні випускників закладів вищої освіти, 3 іншого, що ставить перед національною системою вищої освіти завдання вирішення цих протиріч.

Нагадаємо, що характерною особливістю національного ринку праці за період з 2010 по 2017 роки є значне падіння чисельності економічно активного населення у віці 15 - 70 років відповідно з 20894 тис. осіб до 17854 тис. осіб. У одночас рівень безробіття населення віком 15 - 70 років у цілому по Україні у 2017 р. збільшився в порівнянні з 2014 р. і становить 9,4\% економічно активного населення зазначеного віку (за даними МОП). Упродовж 2015 - 2017 років за кордоном з метою заробітку перебувало 1,3 млн. українських громадян - на 100 тис більше, ніж у 2010 - 2012 роках. Як відзначають аналітики, велика кількість освічених та талановитих людей (інженери, лікарі, фахівці з інформаційних технологій), які працюють за кордоном, сприяють певному рівню «витоку мізків». При цьому у процесі міграції відбувається переважно декваліфікація, коли трудовий мігрант виконує низько кваліфіковану роботу [4].

Можна 3 жалем констатувати, що незважаючи на певні досягнення вищої освіти, які забезпечує нова соціополітична система (демократичність, гнучкість, незаідеологізованість), у масовому вимірі освіта стала менш якісною, а переважна більшість випуск- ників закладів вищої освіти є не конкурентоспроможною на європейському ринку праці. До того ж спостерігається збільшення розриву зв'язків між освітянами і працедавцями, між сферою освіти i ринком праці. Утім, втрата інтелектуального потенціалу дестабілізує та ослаблює країну, а в таких умовах, в яких нині перебуває наша держава, це може стати загрозою національної безпеки. Тому модернізація освіти, основними цілями якої є забезпечення якості, доступності та ефективності, є також гострою і актуальною проблемою [5].

Слід підкреслити, що найбільш болісно кризові явища на ринку праці відчула на собі українська молодь, і перш за все, молоді фахівці, які отримали вищу освіту. Зазначена вище проблема має не тільки економічну, але i, не менш важливу, моральну складову з усіма їі наслідками.

Важливим чинником розв'язання протиріч, які виникли у вітчизняній системі професійної підготовки фахівців, вбачається використання світового та європейського досвіту, котрий демонструє, що тенденції глобалізації, інтеграції та інформатизації суспільства визначили принципово нові пріоритети розвитку освіти у більшості високорозвинутих країн, де вона віднесена до найбільш пріоритетних сфер суспільства. Ця обставина актуалізує необхідність й доцільність аналізу світового європейського досвіду реформування освіти й урахування його у процесі модернізації сучасної вищої освіти в Україні.

Варто відзначити, що одним із провідних світових лідерів у сфері підготовки кваліфікованих кадрів на сьогодні виступає Норвегія. Наш інтерес до норвезької системи вищої освіти зумовлений декількома причинами.

1. У останні роки Норвегія займає перше місце в багатьох рейтингах $\mathrm{OOH}$ (у тому числі в рейтингу розвитку людського потенціалу і рейтингу якості життя) завдяки своїй розвинутій системі освіти. Показники іiі функціонування «перекривають» успіхи більш розвинених в економічному відношенні країн (США, Канада) і стабільно забезпечують Норвегії лідируючі позиції в світі за рівнем іноваційного розвитку. При цьому ринок праці цієї країни є досить стійким, хоча спостерігаються коливання, пов'язані 3 кон'юнктурою цін на нафтопродукти [6].

2. Норвегія являє собою яскравий приклад скандинавської моделі в організації системи вищої освіти. Будучи одночасно егалітарною, централізованою і соціально зорієнтованою, вона відтворює багато характерних рис систем вищої освіти інших скандинавських країн.

Система вищої освіти Норвегії нараховує 8 університетів, 7 спеціалізованих університетських інститутів, 28 університетських коледжів, 2 національних інститути мистецтв, близько двох десятків невеликих приватних навчальних закладів, які, отримують державне фінансування, а більшість їх студентів - державну стипендію.

У закладах вищої освіти Норвегії зареєстровано понад 200 тис. студентів, що становить близько 5\% від усього населення країни. Перший академічний заклад був відкритий у м. Тронхейм у 1760 р. під назвою Королівське норвезьке наукове товариство, 
що сьогодні є частиною Норвезького університету науки і технології.

Перший університет був заснований у 1811 р. в м. Осло. Після Другої світової війни були відкриті університети в містах Берген (1946р.), Тромсе (1972 р.) та інших.

Крім коледжів та університетів в Норвегії існують спеціалізовані інститути, що поєднують у собі риси університетів та коледжів. У більшості з них $\epsilon$ магістратура, але спеціалізовані інститути, як правило, не орієнтовані на наукову діяльність. Інститути такого формату стали виникати на початку 1990х pp. у результаті злиття декількох коледжів. Наприклад, такий інститут було створено в 1994 р на базі шості незалежних коледжів у колишній столиці Норвегії - Бергені. Стратегія його розвитку базувалась на ідеї інтернаціоналізації технічної освіти. Цей заклад вищої освіти веде активну діяльність 3 міжнародного обміну студентами та співпрацює з сорока вищими навчальними закладами Свропи.

Важливим наслідком інтернаціоналізації норвезького вищої освіти в 1990-х рр. стало створення університетських програм англійською мовою Норвезької школи економіки та ділового адміністрування і Норвезької школи менеджменту. Ці програми працюють у двох напрямках, орієнтуючись одночасно на залучення іноземних студентів (частина яких отримує грант на навчання від норвезького уряду) і на підготовку власних висококваліфікованих фахівців - економістів і менеджерів - 3 високим рівнем знання англійської мови. Утім, в Норвегії існують жорсткі квоти на абітурієнтів-іноземців, які щороку оновлюються Міністерством освіти і науки. Процеси інтернаціоналізації вищої освіти розвиваються тут не в логіці ринку, а в логіці соціального планування - під неослабним контролем держави.

Варто зауважити, що Норвегія однією з перших серед країн Європи розпочала реформу вищої освіти відповідно до положень Болонської декларації. Освіта в країні є безкоштовною, тобто студенту потрібно лише внести вступний внесок (30 дол.) і кожен семестр сплачувати внески (37 дол.). До того ж при університетах існують студентські організації, які курують житло, їдальні, медичне обслуговування, що також фінансуються державою. При цьому, студент в Норвегії, зокрема, й студент-іноземець, може отримати кредит або стипендію в Державному фонді освітніх кредитів (Statens Lanekasse) для того, щоб покрити витрати на проживання, харчування та навчальні матеріали. Існує статистика, що, близько, 90\% студентів норвезьких вузів звертаються до Державного фонду й отримують кредити зазвичай на 20 років, але цей кредит може бути частково погашений університетом під час навчання студента. Щорічно 15 тис. норвезьких студентів користуються позиками Державного фонду для отримання освіти за кордоном. Близько 5 тис. студентів беруть позику для участі в міжнародних програмах студентського обміну. Щорічно 6,5\% норвезьких студентів їдуть для продовження освіти за кордон [7].

Одним з основних векторів розвитку норвезької системи вищої освіти в другій половині ХХ ст. став курс на зближення академічної і професійної вищої освіти. Навчальні плани 3ВО набули більшої професійної спрямованості, до них увійшли нові прикладні дисципліни соціального й технічного характеру. Норвезькі університети органічно наблизилися до вимог суспільства, інтегрувалися 3 економічними структурами й інституціями, стали краще розуміти соціальні потреби й активно співпрацювати 3 різними установами для їх задоволення. Тому між коледжами та університетами в Норвегії практично немає статусної нерівності.

Значна частина коледжів сьогодні, в зв'язку з переходом до дворівневої системи «бакалаврат + магістратура», отримають право присвоєння магістерських дипломів. Хоча для вступу до магістратури університету випускник коледжу має пройти додаткові курси і представити атестат про їх успішне закінчення.

Щодо змістового наповнення, освітній процес в коледжах $є$ близьким до університетського (з тією лише різницею, що студенти не займаються науковою діяльністю і не звітуються із загально академічних курсів). Наприклад, у коледжах, так само як і в університетах, $є$ широко поширеною «проектна звітність». Проектні роботи виконуються студентами один раз на рік, починаючи з 2-го курсу. Для виконання проекту студенти розбиваються на групи по 4 - 5 осіб і розподіляють обсяг тексту, який повинен бути зданий до наміченого терміну. Результати проекту широко обговорюються викладачами і студентами. Якщо робота прийнята викладачем курсу, він виставляє всім учасникам проектної групи однакову кількість балів. Групова оцінка - одне 3 основних вимог в системі «колективного навчання» норвезьких коледжів.

До недавнього часу норвезька система вищої освіти вважалася однією з більш егалітарних в Свропі (поряд з освітніми системами Фінляндії і Швеціï). Тобто в ній відсутні інституційні бар'єри; відзначається високий ступінь внутрішньої інтеграції системи освіти, що досягається за рахунок тісного зв'язку шкіл, вузів і місцевої громади. При цьому коледжі з метою запобігання територіальної нерівності в отриманні вищої освіти розподілені по країні пропорційно чисельності населення.

Певним досягненням вищої освіти в Норвегії $є$ низькі показники залежності успішності навчання від соціально-економічного становища сім’ї. Таким чином, ні інституційні, ні територіальні, ні соціально-економічні бар'єри в Норвегії не становлять серйозних перешкод на шляху здобуття вищої освіти. За формальними показниками рівності освітніх можливостей Норвегія також займає провідне місце в Європі, що сприяє зниженню рівня безробіття серед молоді в Норвегії.

Проте сучасна освітня система Норвегії має і певні слабкі сторони. Зупинимося на тих 3 них, які активно дискутуються в педагогічному співтоваристві і які можуть бути прийняті до уваги у процесі модернізації української системи вищої освіти.

Так, французький філософ Ж.-Ф. Ліотар в роботі «Стан постмодерну» порушив проблему трансформації сучасних систем знання в утилітарнопрагматичному напрямку. На думку науковця, ще 
зовсім недавно ідеалом для систем вищої освіти було виховання різнобічної особистості, що володіє фундаментальними теоретичними знаннями, зорієнтованими на вдосконалення та розвиток конкретних прикладних наук й спрямована на цінності свободи, прогресу, справедливості. Стосовно сучасних систем освіти Ж.-Ф. Ліотар констатує пріоритет інших ідеалів. Тобто, основним змістом освітньої практики стає націленість не на розвиток «чистої науки», а на показники корисності, ефективності, прибутковості одержуваного в ЗВО знання. Тобто, однією з основних завдань вищої освіти в інформаційному суспільстві стає формування фахівців, орієнтованих на виконання певних операціональних функцій, дій, затребуваних і прибуткових в соціальній системі [8].

Маємо констатувати факт, що, сучасна молодь віддає пріоритет інформаційно-технічній діяльності і здатна якісно їі здійснювати, що, безумовно, є цінним в ситуації інформатизації сучасного суспільства. Однак слід зазначити і негативні моменти такої ситуації. У значної більшості сучасної молоді спостерігається відсутність інтересу до некомерційних теоретичних, філософських, загально гуманітарних дисциплін, які за своєю природою є нерентабельними.

Звертає на себе увагу і той факт, що частина сучасного студентства оцінює крізь призму утилітаристських цінностей не тільки освіту, а й майбутню професійну діяльність, чекаючи від неї збагачення, успішності, бурхливого кар'єрного зростання. Отже пріоритетами сучасної молоді $є$ такі, як-от: життя в столиці або за кордоном, шикарна машина, власний будинок або апартаменти, власний бізнес [9].

«Ризиковість» певної «дегуманізації» освіти, за оцінкою Ж.-Ф. Ліотара, бачиться у формуванні поколінь функціонерів-роботів, які вважають сенс освіти не в духовній самореалізації, не в особистісному вдосконаленні, а в придбанні технічноналагоджених навичок виконання професійних операцій. 3 іншого боку, все це загрожує «деморалізацією науковців і викладачів», в ситуації кризи теоретичного знання, які починають сумніватися в цінності гуманітарного, неінструментального знання, яке не перекладається на мову комп'ютерних технологій [10].

У цьому контексті Норвегія не є винятком. Так, столичний Університет Короля Фредеріка залишається практично єдиним класичним університетом Норвегії, оскільки більшість норвезьких регіональних вузів мають виражену спеціалізацію. Наприклад, Університет Тронхейма, заснований в 1996 р в результаті злиття Коледжу мистецтв і наук, Музею природознавства і археології та Норвезького університету технологій, є провідним технічним університетом Норвегії і головним науковим центром країни. Тобто, якщо раніше диференціація ЗВО була незначною і статусної нерівності між інститутами академічного і професійного спрямування практично не існувало, то зараз різниця між університетами та коледжами суттєво поглиблюється.

3 точки зору прихильників нововведень, зростання конкурентності $€$ наслідоком посилення інституційної автономії і, більш того, єдиним спосо- бом стимулювання активності навчальних закладів, зокрема, заохочувати науково-дослідну діяльність університетів. Відзначимо, що в Норвегії діє понад 300 науково-дослідних інститутів і близько 40 наукових товариств. Більше половини цих науководослідних установ входять до системи вищої освіти.

Противники таких нововведень вказують на можливість їх негативних наслідків, а саме виникнення «нездорової конкуренції» між ЗВО, що ставить під загрозу єдність освітнього простору країни.

Чи мають в цьому контексті скандинавські країни, в тому числі Норвегія, свого роду імунітет проти впливу ризиків, пов'язаних зі стандартизацією, спеціалізацією, явищами конкуренції в системі вищої освіти? На думку багатьох експертів, - мають. Сутність захисту від таких ризиків вищої освіти Норвегії полягає у забезпеченні рівного доступу до освіти, однорідності результатів навчання, соціальної орієнтації вузів, реалізація «місії надання послуг суспільству» (законодавчо закріпленої як «третьої ролі» університетів). Тому ті проблеми, які з'являються сьогодні у фокусі загальноєвропейських дискусій, зокрема, проблеми усунення економічних або інституційних бар'єрів до отримання освіти, - для країн Скандинавії поки не є актуальними, а їх успішне розв'язання стало умовою розвитку скандинавських систем освіти.

Відзначимо, що системи вищої освіти Скандинавських країн грунтуються на двох підходах, що переважають в європейському освітньому просторі: унітарному та бінарному.

Унітарна, або єдина (Данії та Швеція) система вищої освіти переважно складається з університетів (частка інших, відповідних до них закладів, становить незначний відсоток).

Більш поширеною є бінарна система (Норвегія), у складі якої - університетський та позауніверситетський сектори. У цій системі норвезькі університети пропонують програми $з$ поглибленим теоретичним курсом, спрямованим на грунтовний науковий пошук, а позауніверситетські заклади - програми професійного навчання високого рівня. Характерно, що за кількістю пропонованих програм (їх близько 500) система вищої освіти Норвегії займає лідируючі позиції в світі.

Зміст освітніх програм, базуючись на особистісно зорієнтованому, компетентнісному та діяльнісному підходах, відрізняється варіативністю, гармонійним поєднанням теорії та практики, акцентом на педагогічній практиці, яка розглядається як процес реалізації індивідуальних та творчих можливостей студентів у ході планування та організації навчального процесу. Тобто такий формат програм спрямований на набуття грунтовних, різнобічних знань у поєднанні з профільною освітою, а також дає можливість брати участь у конкретних проектах, реалізація яких здійснюється закладами вищої освіти спільно $з$ підприємствами та організаціями реального сектора економіки, громадських та інших організацій. Варто відзначити, що у сучасний період, з одного боку, відбувається посилення академічного розвитку позауніверситетського сектору, а з іншого, - 
університети активніше беруть участь у професійно зорієнтованій діяльності [11].

Таким чином, реалізується концепція розвитку так званого «трикутника знань», а саме - освіти, досліджень та інновацій. Наша країна також не залишилась осторонь від практичного втілення стратегії трансформації кращих 3ВО в університети дослідницького типу. Отже, головна відмінність дослідницького університету від університету старого типу (який, на жаль, все ще домінує на пострадянському просторі) полягає в тому, що університет стає не місцем репродукції старих знань, а місцем виробництва нових знань. За такої організації науковоосвітнього процесу викладач $\epsilon$ не просто репродуцентом готового знання, а передусім дослідником, що має достатньо свободи, часу та фінансовоорганізаційної інфраструктури для виробництва нового знання та його викладання студентам [10].

ВИСНОВКИ.У зв'язку із зазначеною дискусією й беручи до уваги оцінки і пропозицій відомих вчених, маємо констатувати, що більш суттєвими проблемами та ризиками вищої освіти у контексті сучасних процесів глобалізації та євроінтеграції $\epsilon$ професійний вибір сучасної молоді; реалізація зв'язку вищої освіти з економікою країни, з ринком парці; нестача висококваліфікованих кадрів; працевлаштування випускників закладів вищої освіти; відсутність зв'язків між освітянами та працедавцями; трансформація сучасних систем освіти в утилітарно-прагматичному напрямку; «дегуманізація» сучасної вищої освіти. Проте, крім ризику тотальної прагматизації освіти виникає інший ризик, пов'язаний з розв'язанням проблем зайнятості вчорашніх студентів, забезпечення їх гідно оплачуваною роботою. У іншому випадку виникає висока імовірність нездійсненності цілком законних бажань молоді, а далі - розчарування в собі і в житті, професійна криза, соціальна «розгубленість». I, що також важливо для сучасного соціуму, - загострення соціального розшарування.

У цілому в Норвегії є очевидним прагнення зберегти в системі вищої освіти значну централізацію, вплив і домінуючу роль держави, насамперед, у вирішенні питань соціального характеру (безкоштовне навчання громадян, бюджетні асигнування на розвиток інфраструктури 3ВО, працевлаштування молодих фахівців). В Україні, навпаки, починає переважати тенденція до децентралізації: розширення автономії місцевої влади, збільшення відповідальності організаторів освіти, скорочення державної участі в освіті. Разом $з$ тим, в країні йде пошук мо- делі системи освіти, заснованої на балансі ринкових відносин і державної присутності.

Отже, при певних розбіжностях, які нам слід ураховувати, а саме критично і виважено підходити до вивчення і можливого освоєння норвезької моделі освіти, є очевидним, що розв'язання проблем вищої освіти глобалізаційного, інтеграційного характеру буде тим ефективніше, чим вище буде рівень нашої співпраці в рамках міжнародного співтовариства у сфері освіти.

\section{ЛІТЕРАТУРА}

1. Енциклопедія освіти, (2008), голов. ред. В. Г. Кремень, Акад. пед. наук України, Юрінком Інтер, Київ, 1040 с.

2. Хоружий Г. Ф. (2016), Свропейська політика вищої освіти. Монографія, Дивосвіт, Полтава, $384 \mathrm{c}$.

3. Каленський А. А., Лузан П. Г., Ваніна Н. М., Пащенко Т. М., Кравець С. Г., Пятничук Т. В. (2018), Стандартизація професійної освіти: теорія і практика; монографія, «Полісся», Житомир, 256 с.

4. Державна служба статистики України, електронний ресурс, режим доступу: http:// www. ukrstat.gov.ua/)

5. Кучеренко Д. Г., Мартинюк О. В. (2011), Стратегії розвитку освітніх систем країн світу: монографія, ІПК ДСЗУ, Київ, 312 с.

6. Зарецкий А., Иванова Т. (2014), Промышленные технологии и инновации, СПб, Питер, 480 с.

7. Focus on the structure of higher education in Europe 2003/04 https://publications.europa.eu/en/...2c9 b.../language-enДержавна служба статистики України, електронний ресурс, режим доступу: http:// www. ukrstat.gov.ua/)

8. Лиотар Ж.-Ф. (1998), Состояние постмодерна. Пер. с фр. Шматко Н. А. Серия «Gallicinium», Институт экспериментальной социологии; Спб.: Алетейя, Москва, 160 с.

9. Лисаускене М. В. (2006), Поколение next прагматические перфекционисты или романтики потребления?, Социиол. исследования, .№ 5, С. 111115 .

10. Дмитриченко М. Ф. (2006), Вища освіта і Болонський процес: навч. посіб. для студ. вищ. навч. закл., Знання України, 440 с.

11. Жижко Т. А. (2010), Філософія університетської освіти XXI століття: спроби прогностичного аналізу : монографія, Вид-во НПУ імені М. П. Драгоманова, Київ, 376 с.

\section{ESSENTIAL PROBLEMS AND RISKS OF MODERN HIGHER EDUCATION: NORWEGIAN EXPERIENCE OF THEIR PREVENTION AND SOLVING}

\section{Zhelanov}

G. S. Skovoroda Kharkiv National Pedagogical University

vul. Valentynivska, 2, Kharkiv Ukraine. E-mail: zhdv91@ gmail.com

Purpose. The purpose of the article is to highlight contemporary risks and problems of higher education and to analyse the Norwegian experience of their solution and prevention. Methodology. The study was conducted on the principle of implementing conceptual ideas of a systemic, competence-based and comparative scientific approaches using general scientific methods: analysis, synthesis, comparison, induction and deduction, generalization. Findings. The article highlights more essential problems and risks of higher education in the context of modern processes of globalization and European integration. Attention is focused on the problems of professional choice of modern youth; connection 
of higher education with the economy of the country, with labour market; lack of highly qualified personnel; employment of graduates of higher educational institutions; the absence of connection between educators and employers; transformations of modern education systems in the utilitarian-pragmatic direction; "dehumanization" of modern higher education. The experience of higher education in Norway to prevent and solve its problems and risks has been disclosed. It has been found out that the features of Norway's higher education are the following: egalitarianism, centralization, social orientation, equality of educational opportunities, internationalization; the prevalence of specialized institutions, the implementation of the "knowledge triangle". Originality. More global problems and risks of modern higher education have been highlighted and some aspects of the experience of Norway in their solution and prevention have been analysed, which are more appropriate for implementation in the domestic educational space. Practical value. The article presents a certain practical value for degree-seeking students of the second (master's) and third (educational and scientific) levels of higher education, who study the scientific problems of comparative orientation, as well as in the process of studying the discipline "Pedagogical Comparative Studies". Conclusions. The material presented in the article is focused on finding the ways to solve the problem of the connection of the domestic education with labour market and employers, as well as introduction of the " knowledge triangle" concept as the integration of education, research and innovation in the format of the competence-oriented domestic education realization in the process of implementation of certain aspects of Norway's higher education experience to tackle the most global problems of higher education and prevent some of its risks.

Key words: problems and risks of higher education, labour market, egalitarianism, internationalization of education, dehumanization of education, specialized institutions, "knowledge triangle".

\section{REFERENCES}

1. Kremen, V. G. (2008), Encyclopedia of Education, Academy of Pedagogical Sciences of Ukraine, Kyiv, $1040 \mathrm{p}$.

2. Horuzhyi, G. F. (2016), European Policy of Higher Education: monograph, Divosvit, Poltava, $384 \mathrm{p}$.

3. Kalensky, A. A., Luzan, P. G., Vanin, N. M., Paschenko, T. M., Kravets, S. G., Pyatnychuk, T. V. (2018), Standardization of Vocational Education: Theory and Practice: monograph, Polissya, Zhytomyr, $256 \mathrm{p}$.

4. State Statistics Service of Ukraine, available at: http:// www. ukrstat.gov.ua/ (accessed 2, April 2019).

5. Kucherenko, D. G., Martynyuk, O. V. (2011), Strategies for the development of educational systems of countries of the world: monograph, Kyiv, 312 p.
6. Zaretskiy, A., Ivanova T. (2014), Industrial Technologies and Innovations, St. Petersburg, $480 \mathrm{p}$.

7. Focus on the structure of higher education in Europe 2003/04, available at: (accessed 1, April 2019)

8. Lyotar, J.-P. (1998), Postmodern state, Gallicinium series, Moscow, $160 \mathrm{p}$.

9. Lysauskene, M. V. (2006), The next generation: pragmatic perfectionists or romantics of consumption? Sociological Research, Issue 5, p. 111-115.

10. Dmytrychenko, M. F. (2006), Higher Education and the Bologna Process: teaching. manual for the students of higher educational institutions, Znannya Ukrayiny, Kyiv, 440 p.

11. Zhyzhko, T. A. (2010), Philosophy of university education of the XXI century: attempts of prognostic analysis: monograph, Edition of M.P. Dragomanov Kyiv NPU, Kyiv, 376 p. 